JURNAL PLANS

Penelitian Ilmu Manajemen \& Bisnis

ISSN: $1978-7057$

E-ISSN: 2527-306X

\title{
PENGARUH RASIO SOLVABILITAS, RASIO PROFITABILITAS, LIKUIDITAS DAN LABA PER SAHAM TERHADAP KEBIJAKAN DIVIDEN PADA PERUSAHAAN CONSUMER GOODSYANG TERDAFTAR PADA BURSA EFEK INDONESIA (BEI) PERIODE 2013-2017
}

\author{
Teng Sauh Hwee 1)*, William ${ }^{2)}$, Stephani ${ }^{3)}$, Vera ${ }^{4)}$, Devi Supantri ${ }^{5)}$, \\ Wynne $^{6}$, \& Dandung Prasetya ${ }^{7)}$ \\ Fakultas Ekonomi, Universitas Prima Indonesia \\ E-mail : tengsauhhwee@unprimdn.ac.id
}

\begin{abstract}
Abstrak
Penelitian ini bertujuan untuk menguji dan menganalisis pengaruh rasio solvabilitas, rasio profitabilitas, likuiditas dan laba per saham terhadap kebijakan dividen pada perusahaan consumer goods yang terdaftar pada Bursa Efek Indonesia periode 2013-2017. Metode penelitian yang digunakan yaitu pendekatan kuantitatif, jenis penelitian deskriptif dan bersifat eksploratif. Populasi dalam penelitian ini adalah 45 perusahaan Consumer Goods. Teknik pengambilan sampel adalah Purposive Sampling, yaitu sebanyak 10 Perusahaan. Teknik analisis data menggunakan model analisis regresi linear berganda, koefisien dertiminasi, Uji-F, dan Uji-t untuk mendapatkan model regresi yang baik. Hasil penelitian hipotesis secara simultan menunjukkan rasio solvabilitas, rasio profitabilitas, likuiditas dan laba per saham berpengaruh positif dan signifikan terhadap kebijakan dividen pada perusahaan consumer goods yang terdaftar pada Bursa Efek Indonesia periode 2013-2017.
\end{abstract}

\section{Kata kunci : Total Debt to Equity Ratio, Return on Equity, Current Ratio, Earning Per Share dan Kebijakan Dividen.}

\begin{abstract}
This study aims to examine and analyze the effect of solvency ratios, profitability ratios, liquidity and earnings per share on dividend policy in consumer goods companies listed on the Indonesia Stock Exchange for the period 2013-2017. The research method used is quantitative approach, descriptive research type and explorative. The population in this study were 45 Consumer Goods companies. The sampling technique is purposive sampling, which is as many as 10 companies. Data analysis techniques used multiple linear regression analysis models, determination coefficients, F-Tests, and T-Tests to obtain a good regression model. The results of simultaneous hypothesis research indicate solvency ratios, profitability ratios, liquidity and earnings per share have positive and significant effect on dividend policy in consumer goods companies listed on the Indonesia Stock Exchange for the period 2013-2017.
\end{abstract}

Keywords : $\quad$ Total Debt to Equity Ratio, Return on Equity, Current Ratio, Earning Per Shareand Dividend Policy. 
JURNAL PLANS

Penelitian Ilmu Manajemen \& Bisnis

ISSN: $1978-7057$

E-ISSN: 2527-306X

\section{PENDAHULUAN}

Saat ini, investasi bisa dilakukan dengan berbagai cara, di antaranya bisa melalui pasar uang dan pasar modal. Investasi pada pasar uang bisa menggunakan beberapa instrumen seperti treasury bills, sertifikat deposito, surat berharga komersil, akseptasi bank dan eurodolars, sedangkan di lain pihak seperti pasar modal bisa digunakan sebagai tempat untuk melakukan transaksi antara pihak yang sedang membutuhkan dana dengan pihak yang menyediakan dana guna memberikan keuntungan bagi kedua belah pihak. Oleh karena itu seorang investor tentunya harus mampu untuk memberikan gambaran tentang bagaimana menempatkan investasinya agar dividen ataupun tingkat pengembalian yang diharapkan bisa maksimal, dengan cara mengelola investasinya dengan memperhatikan kondisi pasar modal agar terhindar juga dari resiko investasi yang bisa saja merugikan.

Dividen merupakan salah satu keuntungan yang diharapkan oleh investor di pasar modal, sehingga perusahaan yang membagikan dividen yang rutin dan relatif tinggi cenderung lebih diminati investor. Kebijakan dividen (dividend policy) adalah kebijakan yang berkaitan dengan pembayaran dividen oleh perusahaan berupa penentuan besarnya pembagian dividen dan besarnya laba ditahan untuk kepentingan perusahaan. Tidak semua perusahaan yang terdaftar di Bursa Efek Indonesia (BEI) membagikan dividen kepada pemegang saham yang disebabkan oleh adanya pertimbangan-pertimbangan

perusahaan dalam membuat keputusan tentang kebijakan dividen dalam perusahaan mereka.
Gambaran mengenai dividen ini, peneliti menggunakan empat faktor atau variabel yaitu, rasio solvabilitas, rasio profitabilitas, likuiditas dan earning per share sebagai acuan untuk mengetahui keadaan dividen yang dihasilkan ketika terdapat empat faktor tersebut. Peneliti memilih keempat faktor tersebut karena ingin membuktikan bahwa apakah keempat variabel tersebut memiliki hubungan terhadap kebijakan dividen yang diberikan oleh perusahaan kepada para pemegang saham.

Penggunaan hutang dalam keputusan pendanaan perusahaan akan berdampak pada solvabilitas perusahaan. Hal ini dapat dilihat pada rasio Total Debt To Equity Ratioatau Debt To Equity Ratio (DER) merupakan salah satu rasio solvabilitas. Penggunaan hutang mempunyai manfaat bagi perusahaan karena dapat mengurangi beban pajak. Namun di sisi lain, rasio hutang yang tinggi akan mempengaruhi likuiditas secara langsung. Penggunaan hutang yang besar akan mengurangi kas perusahaan dalam bentuk pembayaran bunga dan pokok pinjaman, yang pada akhirnya berdampak pada pengurangan dividen yang dibagikan.

$$
\text { Rasio }
$$

profitabilitas menunjukkan sekelompok rasio yang menunjukkan seberapa besar kemampuan perusahaan menghasilkan keuntungan. Rasio profitabilitas diproksikan dengan Return On Equity (ROE) yangmenjelaskan bagaimana hasil akhir yang diperoleh dari seluruh kebijakan keuangan dan keputusan operasional yang dilakukan perusahaan sehingga bisa memberikan informasi kepada para pemegang saham atas berapa laba yang diperoleh dari dana yang diinvestasikannya. 
JURNAL PLANS

Penelitian Ilmu Manajemen \& Bisnis

ISSN: $1978-7057$

E-ISSN: 2527-306X

\begin{abstract}
Rasio likuiditas adalah rasio yang menunjukkan kemampuan perusahaan untuk memenuhi kewajiban finansialnya dalam jangka pendek dengan dana lancar yang tersedia. Salah satu variabel yang digunakan dari rasio likuiditas adalah Current Ratio, yaitu rasio yang membagi aktiva lancar dengan hutang lancar. Rasio ini bisa menjadi bahan pertimbangan bagi para pemegang saham untuk menilai sejauh mana perusahaan bisa memberikan dividen yang sudah dijanjikan.
\end{abstract}

Earning Per Share merupakan kemampuan perusahaan untuk menghasilkan keuntungan per lembar saham pemilik. Earning Per Share yang tinggi dikarenakan perusahaan memiliki keuntungan yang besar sehingga tingkat dividenyang akan dibayarkan semakin besar.Sebaliknya, Earning Per Share yang rendah dikarenakan perusahaan memiliki keuntungan yang kecilyang menegakibatkan tingkat dividen yang diterima investor kecil.

Emiten saham yang terus konsisten membagikan dividen, bagi para investor diberikan perhatian lebih. Tercatat ada beberapa emiten Bluechips yang cukup royal membagi dividen. Seperti, PT. Unilever Indonesia, Tbk (UNVR). UNVR masuk dalam anggota LQ-45 yang dianggap mempunyai tingkat pembagian dividen tertinggi akibat rasio dividen terhadap laba bersih (dividend payout ratio) UNVR juga kerap mencapai hingga 100\%. Ada juga PT. Gudang Garam, Tbk (GGRM), PT. Indofood Sukses Makmur, Tbk (INDF) serta PT. HM Sampoerna, Tbk (HMSP) sebagai emiten konsumer yang selalu tercatat sebagai pemberi dividen besar. Hal ini dianggap wajar pasalnya, sektor emiten konsumer ini tergolong sektor yang defensif. Maka jika ada guncangan ekonomi, sektor konsumer tetap dapat mempertahankan margin labanya, karena hampir semua orang membutuhkan barang konsumsi. Faktor fundamental perseroan juga berpengaruh dalam pembagian besaran dividen yang dibagikan. Perseroan yang sudah matang dan menguasai pangsa pasar, biasanya tidak banyak melakukan ekspansi yang massif, membuat, perseroan tidak masalah jika sebagian besar laba emiten mereka dikembalikan kepada pemegang saham dalam bentuk dividen (https://www.valas.news).

Alasan pemilihan perusahaan Consumer Goods karena salah satu perusahaan manufaktur yang terdiri dari berbagai sub sektor seperti perusahaan makanan dan minuman, perusahaan farmasi, perusahaan rokok, perusahaan kosmetik, perusahaan peralatan rumah tangga dan lain-lain. Di Indonesia sendiri perusahaan Consumer Goods sangat berkembang dengan pesat yang dapat dilihat dengan bertambahnya perusahaan Consumer Goods yang terdaftar di Bursa Efek Indonesia tahun 2017. Hal ini dikarenakan saham perusahaan Consumer Goods yang paling tahan dengan krisis moneter atau ekonomi, di bandingkan dengan sektor lain karena dalam kondisi apapun sebagian perusahaan Consumer Goods mampu menghasilkan keuntungan yang cukup besar sehingga dapat menarik perhatian investor untuk berinvestasi di perusahaan Consumer Goods. Untuk melihat hubungan variabel rasio solvabilitas, rasio profitabilitas, likuiditas dan laba per saham terhadap kebijakan dividen, peneliti menguji tiga perusahaan Consumer Goods periode 2013-2017. 
JURNAL PLANS

Penelitian Ilmu Manajemen \& Bisnis

ISSN: $1978-7057$

E-ISSN: 2527-306X

Tabel 1. Tabel Fenomena Periode 2013-2017 (Dalam Jutaan Rupiah)

\begin{tabular}{|c|c|c|c|c|c|c|c|}
\hline Kode & Nama & Tahun & $\begin{array}{c}\text { Total } \\
\text { Hutang }\end{array}$ & $\begin{array}{l}\text { Laba } \\
\text { Bersih }\end{array}$ & $\begin{array}{l}\text { Aktiva } \\
\text { Lancar }\end{array}$ & $\begin{array}{l}\text { Jumlah } \\
\text { Lembar } \\
\text { Saham }\end{array}$ & $\begin{array}{l}\text { Dividen } \\
\text { per } \\
\text { Share }\end{array}$ \\
\hline \multirow[t]{5}{*}{ GGRM } & \multirow{5}{*}{$\begin{array}{l}\text { PT Gudang } \\
\text { Garam Tbk. }\end{array}$} & 2013 & 21.353 .980 & 4.383 .932 & 34.604 .461 & 1.924 & 817,03 \\
\hline & & 2014 & 24.991 .880 & 5.395 .293 & 38.532 .600 & 1.924 & 822,70 \\
\hline & & 2015 & 25.497 .504 & 6.458 .516 & 42.568 .431 & 1.924 & 814,95 \\
\hline & & 2016 & 23.387 .406 & 6.586 .081 & 41.933 .173 & 1.924 & $2.611,42$ \\
\hline & & 2017 & 24.572 .266 & 7.703 .622 & 43.764 .490 & 1.924 & $2.624,06$ \\
\hline \multirow[t]{5}{*}{ HMSP } & \multirow{5}{*}{$\begin{array}{l}\text { PT HM } \\
\text { Sampoerna } \\
\text { Tbk. }\end{array}$} & 2013 & 13.249 .559 & 10.807 .957 & 21.247 .830 & 4.383 & $2.269,00$ \\
\hline & & 2014 & 14.882 .516 & 10.014 .995 & 20.777 .514 & 4.383 & $2.430,00$ \\
\hline & & 2015 & 5.99 & 10.3 & 29.8 & 4.653 & $2.632,81$ \\
\hline & & 2016 & 8.33 & 12.53 & 33.647 .496 & 116.318 & 89,00 \\
\hline & & 2017 & 9.028 .078 & 12.483 .134 & 34.180 .353 & 116.318 & 107,70 \\
\hline \multirow[t]{5}{*}{ INDF } & \multirow{5}{*}{$\begin{array}{l}\text { PT Indofood } \\
\text { Sukses } \\
\text { Makmur Tbk. }\end{array}$} & 2013 & 39.719 .660 & 5.161 .247 & 32.464 .497 & 8.780 & 247,92 \\
\hline & & 2014 & 44.710 .509 & 4.812 .618 & 40.995 .736 & 8.780 & 197,57 \\
\hline & & 2015 & 48.709 .933 & 4.867 .347 & 42.816 .745 & 8.780 & 285,71 \\
\hline & & 2016 & 38.233 .092 & 4.984 .305 & 28.985 .443 & 8.780 & 223,77 \\
\hline & & 2017 & 41.182 .764 & 5.039 .068 & 32.515 .399 & 8.780 & 311,48 \\
\hline
\end{tabular}

Sumber Data : http://www.idx.co.id

Total Hutang pada PT. Gudang

Garam Tbk., tahun 2014 mengalami kenaikan menjadi $\mathrm{Rp}$ 24.991.880.000.000 atau sebesar $17,04 \%$ dari tahun 2013, sedangkan dividen per share tahun 2014 mengalami kenaikan menjadi Rp. 822.700 .000 atau sebesar $0,69 \%$ dari tahun 2013. Laba Bersih pada PT. Indofood Sukses Makmur Tbk., tahun 2016 mengalami kenaikan menjadi Rp 4.984.305.000.000 atau $2,40 \%$ dari tahun 2015,sedangkan dividen per share tahun 2016 mengalami penurunan menjadi Rp. 233.770.000 atau $21,68 \%$ dari tahun 2015.

Aktiva Lancar pada PT. Gudang Garam Tbk., tahun 2015 mengalami kenaikan menjadi $\mathrm{Rp}$ 42.568.431.000.000 atau $10,47 \%$ dari tahun 2014, sedangkan dividen per share tahun 2015 mengalami penurunan menjadi Rp. 814.950.000 atau $0,94 \%$ dari tahun 2014. Jumlah Lembar Sahampada PT. HM Sampoerna Tbk., tahun 2016 mengalami kenaikan menjadi Rp 116.318 .000 .000 atau $2.399,85 \%$ dari tahun 2015, sedangkan dividen tahun 2016 mengalami penurunan menjadi

Rp. 89.000 .000 atau $96,62 \%$ dari tahun 2015.

\section{Pengaruh Solvabilitas terhadap Kebijakan Dividen}

Menurut Musthafa (2017: 142), kalau perusahaan akan melunasi utangnya dengan segera, maka dividen bisa kecil atau laba ditahan, dan sebaliknya kalau perusahaan tidak segera melunasi utangnya atau tidak ada utang yang dibayar, maka dividen bisa dibayar cukup besar oleh perusahaan dari keuntungan yang diperoleh.

Menurut Hery (2015: 191), apabila perusahaan memperoleh penghasilan lebih dari dana yang dipinjamnya dibandingkan dengan bunga yang harus dibayarkan kepada kreditor, maka kelebihannya tersebut akan memperbesar pengembalian/imbal hasil (return) bagi pemilik.

Menurut Masdupi (2012:4), peningkatan utang akan menyebabkan ketergantungan terhadap kreditor juga akan semakin bertambah. Semakin tinggi rasio ini berarti semakin besar tingkat utang dalam struktur modal dan perusahaan akan membutuhkan dana lebih dalam pembayaran pokok 
JURNAL PLANS

Penelitian Ilmu Manajemen \& Bisnis

ISSN: $1978-7057$

E-ISSN: 2527-306X

pinjaman beserta bunganya. Hal ini mengakibatkan berkurangnya jumlah kas dalam perusahaan dan akan berdampak pada turunnya rasio pembayaran dividen.

\section{Pengaruh Profitabilitas terhadap Kebijakan Dividen}

Menurut Sudana (2015: 197), perusahaan hanya akan meningkatkan dividen payout ratio, jika pendapatan perusahaan meningkat dan perusahaan merasa mampu untuk mempertahankan kenaikan pendapatan tersebut dalam jangka waktu panjang. Menurut Husnan dan Pudjiastuti (2012: 298), peningkatan pembayaran dividen hanya dimungkinkan apabila laba yang diperoleh oleh perusahaan juga meningkat. Dan sebaliknya perusahaan yang tidak bisa membagikan dividen yang makin besar apabila laba yang diperoleh tidak meningkat. Menurut Mulyawan (2015: 257), semakin besar laba yang diperoleh, semakin besar dividen yang dibayarkan. Demikian juga sebaliknya, apabila laba kecil dividen yang dibayarkan juga kecil.

\section{Pengaruh Likuiditas terhadap Kebijakan Dividen}

Menurut Sudana (2015: 195), semakin tinggi tingkat likuiditas perusahaan, semakin besar dividen tunai yang mampu dibayar perusahaan kepada pemegang saham, dan sebaliknya. Menurut Musthafa (2017: 142), kalau likuiditas perusahaan baik, dividen dapat dibagikan lebih besar, begitu pula sebaliknya apabila likuiditas perusahaan tidak baik, maka dividen bisa kecil atau bisa tidak dibagikan sebagai dividen tetapi ditahan oleh perusahaan yang disebut laba ditahan. Menurut Sinaga (2014: 380), laba ditahan biasanya diinvestasikan dalam aktiva yang dibutuhkan untuk menjalankan usaha. Makin kuat posisi likuiditas perusahaan makin besar dividen yang dibayarkan.

\section{Pengaruh Earning per Shareterhadap Kebijakan Dividen \\ Menurut Darmadji dan}

Fakhruddin (2012: 154), makin tinggi nilai Earning per Share (EPS) tentu saja menggembirakan pemegang saham karena makin besar laba yang disediakan untuk pemegang saham dan kemungkinan peningkatan jumlah dividen yang diterima pemegang saham. Menurut Mulyawan (2015: 257), semakin besar laba yang diperoleh, semakin besar dividen yang dibayarkan. Demikian juga sebaliknya, apabila laba kecil dividen yang dibayarkan juga kecil. Menurut Diantini (2016:6805), nilai suatu perusahaan pada dasarnya tergantung pada kemampulabaan perusahaan yang merupakan sumber dana untuk membayar dividen. Sehingga semakin tinggi nilai Earning per Share (EPS) akan menyebabkan semakin besar laba dan kemungkinan peningkatan jumlah dividen yang diterima pemegang saham.

\section{METODE PENELITIAN}

Pendekatan penelitian yang digunakan adalah penelitian kuantitatif. Jenis penelitian yang digunakan adalah penelitian deskriptif. Penelitian yang dilakukan merupakan penelitian eksploratif. Populasi yang digunakan dalam penelitian ini adalah seluruh perusahaan consumer goodsyang terdaftar di Bursa Efek Indonesia selama periode 2013-2017 yang berjumlah 45 perusahaan. Penelitian ini menggunakan teknik purposive samplingdimana teknik mengambil sampel dari purposive sampling disesuaikan dengan kriteria-kriteria yang telah ditentukan. Teknik pengumpulan data dalam penelitian ini diperoleh melalui studi dokumentasi, 
JURNAL PLANS

Penelitian Ilmu Manajemen \& Bisnis

ISSN: $1978-7057$

E-ISSN: 2527-306X

dengan mengumpulkan data sekunder dari laporan keuangan perusahaan Consumer Goods yang dimuat dalam situs resmi Bursa Efek Indonesia, yaitu www.idx.co.id,buku, jurnal dan laporan penelitian yang berkaitan dengan masalah yang diteliti.

\section{HASIL DAN PEMBAHASAN \\ Hasil Penelitian \\ Analisis Regresi Linier Berganda}

Analisis regresi linier berganda digunakan untuk mengetahui ada tidaknya pengaruh antara variabel independen terhadap variabel dependen. Hasil analisis regresi linier berganda dapat dilihat sebagai berikut:

Ln $Y=0,099029+0,138070 X_{1}+0,423412 X_{2}+$ $0,076051 X_{3}+0,000001 X_{4}$

Hasil persamaan regresi linier berganda di atas dapat dijelaskan sebagai berikut :

1. Konstanta (a) mempunyai koefisien regresi sebesar 0,099029. Artinya jika variabel rasio solvabilitas, rasio profitabilitas, likuiditas dan laba per saham dianggap nol, maka kebijakan dividen mengalami penurunan sebesar 0,099029.

2. Variabel rasio solvabilitas mempunyai nilai koefisien regresi positif sebesar 0,138070. Artinya bahwa setiap kenaikan variabel rasio solvabilitas sebesar 1 satuan, maka akan terjadi peningkatankebijakan dividen sebesar 0,138070 satuan dengan asumsi variabel lain dianggap nol.

3. Variabel rasio profitabilitas mempunyai nilai koefisien regresi positif sebesar 0,423412. Artinya bahwa setiap kenaikan variabel rasio profitabilitas sebesar 1 satuan, maka akan terjadi peningkatankebijakan dividen sebesar 0,423412 satuan dengan asumsi variabel lain dianggap nol.

4. Variabel likuiditas mempunyai nilai koefisien regresi positif sebesar 0,076051. Artinya bahwa setiap kenaikan variabel likuiditas sebesar 1 satuan, maka akan terjadi peningkatankebijakan dividen sebesar 0,076051 satuan dengan asumsi variabel lain dianggap nol.

5. Variabel laba per saham mempunyai nilai koefisien regresi positif sebesar 0,000001. Artinya bahwa setiap kenaikan variabel laba per saham sebesar 1 satuan, maka akan terjadi peningkatan kebijakan dividen sebesar 0,000001 satuan dengan asumsi variabel lain dianggap nol.

\section{Koefisien Determinasi}

Koefisiendeterminasi pada intinya mengukur seberapa jauh kemampuan variasi variabel independen dalam menerangkan variabel dependen. Hasil uji koefisien determinasi dapat dilihat dari nilai adjusted $R$ square sebesar 0,396 yang menunjukkan bahwa kebijakan dividen pada perusahaan consumer goods yang terdaftar pada Bursa Efek Indonesia periode 2013-2017 dipengaruhi oleh keempat variabel yaitu variabel rasio solvabilitas, rasio profitabilitas, likuiditas dan laba per sahamsebesar 0,396 atau $39,6 \%$ sedangkan sisanya sebesar $60,4 \%$ dapat dijelaskan variabel lainnya yang belum diteliti dalam penelitian ini.

\section{Pengujian Hipotesis Secara Simultan}

Pengujian ini untuk menguji pengaruh rasio solvabilitas, rasio profitabilitas, likuiditas dan laba per sahamterhadap kebijakan dividenpada perusahaan consumer goodsyang terdaftar pada Bursa Efek Indonesia periode 2013-2017secara simultan. Pengujian hipotesis ini dilakukan 
JURNAL PLANS

Penelitian Ilmu Manajemen \& Bisnis

ISSN: $1978-7057$

E-ISSN: 2527-306X

dengan menggunakan regresi berganda dengan bantuan SPSS versi 20. Hasil pengujian hipotesis secara simultan dapat dilihat sebagai berikut : Dari perhitungan diperoleh nilai $\mathrm{F}_{\text {hitung }}$ lebih besar dari $F_{\text {tabel }}$ yaitu $9,036>2,58$ dan jika dilihat dari nilai sig hitung adalah $0,000<0,05$ maka keputusannya menolak $\mathrm{H}_{0}$ dan menerima $\mathrm{H}_{5}$ yang berarti bahwa secara simultan rasio solvabilitas, rasio profitabilitas, likuiditas dan laba per saham berpengaruh positif dan signifikan terhadap kebijakan dividenpada perusahaan consumer goods yang terdaftar pada Bursa Efek Indonesia periode 2013-2017.

\section{Pengujian Hipotesis Secara Parsial}

Uji ini digunakan untuk menentukkan pengaruh rasio solvabilitas, rasio profitabilitas, likuiditas dan laba per saham secara parsial terhadap kebijakan dividenpada perusahaan consumer goods yang terdaftar pada Bursa Efek Indonesia periode 2013-2017. Hasil pengujian hipotesis secara parsialdapat dilihat sebagai berikut :

1. Berdasarkan analisis data pengujian $\mathrm{H}_{1}$ menunjukkan nilai $t_{\text {hitung }}$ sebesar 1,153 lebih kecil dari $t_{\text {tabel }}$ sebesar 2,014 dan nilai sig. hitung sebesar 0,255 lebih besar dari 0,05 maka keputusannya menerima $\mathrm{H}_{0}$ dan menolak $\mathrm{H}_{1}$ yang berarti rasio solvabilitas tidak berpengaruh dan tidak signifikan terhadap kebijakan dividenpada perusahaan consumer goods yang terdaftar pada Bursa Efek Indonesiaperiode 2013-2017.

2. Berdasarkan analisis data pengujian $\mathrm{H}_{2}$ menunjukkan nilai $t_{\text {hitung }}$ sebesar 2,349 lebih besar dari tabel sebesar 2,014 dan nilai sig. hitung sebesar 0,023 lebih kecil dari 0,05 maka keputusannya menolak $\mathrm{H}_{0}$ dan menerima $\mathrm{H}_{2}$ yang berarti rasio profitabilitas berpengaruh positif dan signifikan terhadap kebijakan dividenpada perusahaan consumer goods yang terdaftar pada Bursa Efek Indonesia periode 2013-2017.

3. Berdasarkan analisis data pengujian $\mathrm{H}_{3}$ menunjukkan nilai $t_{\text {hitung }}$ sebesar 3,345 lebih besar dari $t_{\text {tabel }}$ sebesar 2,014 dan nilai sig. hitung sebesar 0,002 lebih kecil dari 0,05 maka keputusannya menolak $\mathrm{H}_{0}$ dan menerima $\mathrm{H}_{3}$ yang berarti likuiditas berpengaruh positif dan signifikan terhadap kebijakan dividenpada perusahaan consumer goods yang terdaftar pada Bursa Efek Indonesia periode 2013-2017.

4. Berdasarkan analisis data pengujian $\mathrm{H}_{4}$ menunjukkan nilai $\mathrm{t}_{\text {hitung }}$ sebesar 0,122 lebih kecil dari $t_{\text {tabel }}$ sebesar 2,014 dan nilai sig. hitung sebesar 0,903 lebih besar dari 0,05 maka keputusannya menerima $\mathrm{H}_{0}$ dan menolak $\mathrm{H}_{4}$ yang berarti laba per saham tidak berpengaruh dan tidak signifikan terhadap kebijakan dividenpada perusahaan consumer goods yang terdaftar pada Bursa Efek Indonesiaperiode 2013-2017.

\section{Pembahasan \\ Pengaruh Rasio Solvabilitas, Rasio Profitabilitas, Likuiditas Dan Laba Per Saham Terhadap Kebijakan Dividen}

Berdasarkan hasil penelitian ini diperoleh hasil perhitungan dengan nilai $F_{\text {hitung }}$ lebih besar dari $F_{\text {tabel }}$ yaitu $9,036>2,58$ dan jika dilihat dari nilai sig hitung adalah $0,000<0,05$ maka keputusannya menolak $\mathrm{H}_{0}$ dan menerima $\mathrm{H}_{5}$ yang berarti bahwa secara simultan rasio solvabilitas, rasio profitabilitas, likuiditas dan laba per saham berpengaruh positif dan signifikan terhadap kebijakan dividen pada perusahaan consumer goodsyang 
JURNAL PLANS

Penelitian Ilmu Manajemen \& Bisnis

ISSN: $1978-7057$

E-ISSN: 2527-306X

terdaftar pada Bursa Efek Indonesia periode 2013-2017.

\section{Pengaruh Rasio Solvabilitas Terhadap Kebijakan Dividen}

Berdasarkan hasil penelitian ini diperoleh hasil perhitungan dengan nilai $t_{\text {hitung }}$ sebesar 1,153 lebih kecil dari $\mathrm{t}_{\text {tabel }}$ sebesar 2,014 dan nilai sig. hitung sebesar 0,255 lebih besar dari 0,05 maka keputusannya menerima $\mathrm{H}_{0}$ dan menolak $\mathrm{H}_{1}$ yang berarti rasio solvabilitas tidak berpengaruh dan tidak signifikan terhadap kebijakan dividenpada perusahaan consumer goods yang terdaftar pada Bursa Efek Indonesia periode 2013-2017. Hasil penelitian ini sesuai dengan hasil penelitian yang dilakukan sebelumnya oleh Prawira (2014) dan Natsir (2015) yang menunjukkan bahwa rasio solvabilitas tidak berpengaruh dan tidak signifikan terhadap kebijakan dividen. Hasil penelitian yang menyatakan tidak berpengaruh dikarenakan semakin rendah kemampuan perusahaan dalam melakukan pembayaran dividen. Komitmen perusahaan untuk melakukan pembayaran dividen tidak dipengaruhi oleh besar kecilnya hutang perusahaan bahkan kenaikan hutang dapat meningkatkan kemampuan perusahaan membayar dividen selama penggunaan hutang harus selalu diiringi dengan peningkatan laba perusahaan.

\section{Pengaruh Rasio Profitabilitas Terhadap Kebijakan Dividen}

Berdasarkan hasil penelitian ini diperoleh hasil perhitungan dengannilai $t_{\text {hitung }}$ sebesar 2,349 lebih besar dari $t_{\text {tabel }}$ sebesar 2,014 dan nilai sig. hitung sebesar 0,023 lebih kecil dari 0,05 maka keputusannya menolak $\mathrm{H}_{0}$ dan menerima $\mathrm{H}_{2}$ yang berarti rasio profitabilitas berpengaruh positif dan signifikan terhadap kebijakan dividen pada perusahaan consumer goods yang terdaftar pada Bursa Efek Indonesia periode 2013-2017. Hasil penelitian ini sesuai dengan hasil penelitian yang dilakukan sebelumnya oleh Prawira (2014) dan Natsir (2015) yang menunjukkan bahwa rasio profitabilitas berpengaruh positif dan signifikan terhadap kebijakan dividen. Hasil penelitian yang menyatakan berpengaruh dikarenakan keuntungan yang diperoleh oleh perusahaan merupakan sinyal yag positif bagi para pemegang saham untuk memperoleh dividen yang diharapkan. Semakin besar keuntungan yang diperoleh oleh perusahaan, maka akan memeberikan dividen yang besar pula terhadap para pemegang saham. Selain itu juga, dividen yang diberikan atas keuntungan yang diperoleh oleh perusahaan bisa menjadi bahan pertimbangan untuk mengelola investasi saat ini sehingga hubungan antara laba dan dividen menurut hasil penelitian ini sangat linear karena saling berhubungan.

\section{Pengaruh Likuiditas Terhadap} Kebijakan Dividen

Berdasarkan hasil penelitian ini diperoleh hasil perhitungan dengan nilai $t_{\text {hitung }}$ sebesar 3,345 lebih besar dari $t_{\text {tabel }}$ sebesar 2,014 dan nilai sig. hitung sebesar 0,002 lebih kecil dari 0,05 maka keputusannya menolak $\mathrm{H}_{0}$ dan menerima $\mathrm{H}_{3}$ yang berarti likuiditas berpengaruh positif dan signifikan terhadap kebijakan dividen pada perusahaan consumer goods yang terdaftar pada Bursa Efek Indonesia periode 2013-2017. Hasil penelitian ini sesuai dengan hasil penelitian yang dilakukan sebelumnya oleh Diantini (2016) yang menunjukkan bahwa likuiditas berpengaruh positif dan signifikan terhadap kebijakan dividen. Hasil penelitian yang menyatakan berpengaruh dikarenakan perusahaan 
JURNAL PLANS

Penelitian Ilmu Manajemen \& Bisnis

ISSN: $1978-7057$

E-ISSN: 2527-306X

yang mampu menjaga likuiditas keuangannya akan mempunyai kesempatan lebih besar untuk membagikan dividen karena perusahaan tidak terbebani oleh kewajiban jangka pendeknya.

\section{Pengaruh Laba Per Saham} Terhadap Kebijakan Dividen

Berdasarkan hasil penelitian ini diperoleh hasil perhitungan dengan nilai $t_{\text {hitung }}$ sebesar 0,122 lebih kecil dari $\mathrm{t}_{\text {tabel }}$ sebesar 2,014 dan nilai sig. hitung sebesar 0,903 lebih besar dari 0,05 maka keputusannya menerima $\mathrm{H}_{0}$ dan menolak $\mathrm{H}_{4}$ yang berarti laba per saham tidak berpengaruh dan tidak signifikan terhadap kebijakan dividenpada perusahaan consumer goods yang terdaftar pada Bursa Efek Indonesia periode 2013-2017.

Hasil penelitian ini sesuai dengan hasil penelitian yang dilakukan sebelumnya oleh penelitian Jumingan (2014) yang menunjukkan bahwa Earning Per Share tidak berpengaruh terhadap Dividend Payout Ratio. Hasil penelitian yang menyatakan tidak berpengaruh dikarenakan hal ini dipengaruhi adanya kecenderungan perusahaan dalam mengalokasikan laba yang diperoleh untuk memenuhi kebutuhan dana perusahaan dan menjaga likuiditas perusahaan. Kebutuhan dana perusahaan digunakan perusahaan untuk menjalankan usahanya dan melakukan ekspansi.

\section{SIMPULAN}

Secara parsial, rasio solvabilitas tidak berpengaruh dan tidak signifikan terhadap kebijakan dividenpada perusahaan consumer goodsyang terdaftar pada Bursa Efek Indonesia periode 2013-2017 karena nilai $\mathrm{t}_{\text {hitung }} 1,153<\mathrm{t}_{\text {tabel }} 2,014$ dan nilai signifikansi $\quad 0,255>0,05$. Secara parsial, rasio profitabilitas berpengaruh positif dan signifikan terhadap kebijakan dividenpada perusahaan consumer goodsyang terdaftar pada Bursa Efek Indonesia periode 20132017 karena nilai $t_{\text {hitung }} 2,349$ $>t_{\text {tabel }} 2,014$ dan nilai signifikansi $0,023<0,05$. Secara parsial, likuiditas berpengaruh positif dan signifikan terhadap kebijakan dividenpada perusahaan consumer goodsyang terdaftar pada Bursa Efek Indonesia periode 2013-2017 karena nilai $t_{\text {hitung }} 3,345>t_{\text {tabel }} 2,014$ dan nilai signifikansi $0,002<0,05$. Secara parsial, laba per saham tidak berpengaruh dan tidak signifikan terhadap kebijakan dividenpada perusahaan consumer goods yang terdaftar pada Bursa Efek Indonesia periode 2013-2017karena nilai $t_{\text {hitung }} 0,122<t_{\text {tabel }} 2,014$ dan nilai signifikansi $\quad 0,903>0,05$. Secara simultan, rasio solvabilitas, rasio profitabilitas, likuiditas dan laba per saham berpengaruh positif dan signifikan terhadap kebijakan dividenpada perusahaan consumer goods yang terdaftar pada Bursa Efek Indonesia periode 2013-2017 karena nilai $F_{\text {hitung }}$ lebih besar dari $F_{\text {tabel }}$ yaitu $9,036>2,58$ dan nilai sig hitung 0,000 $<0,05$.

\section{DAFTAR PUSTAKA}

Diantini, Olivia. 2016. Pengaruh Earning Per Share, Tingkat Pertumbuhan Perusahaan Dan Current Ratio Terhadap Kebijakan Dividen.E-Jurnal Manajemen Unud, Vol. 5, No. 11, 2016: 6795-6824.

Hery. 2015. Analisis Laporan Keuangan: Pendekatan Rasio Keuangan. Yogyakarta: CAPS.

Husnan, Suad dan Esty Pudjiastuti. 2012. Manajemen Keuangan, 
Edisi Keenam. Yogyakarta: UPP AMP YKPN.

http://www.idx.co.id di akses tanggal

27 Maret 2019

Masdupi, Erni. 2012. Pengaruh Insider Ownership, Struktur Modal, Dan Pertumbuhan Perusahaan Terhadap Kebijakan Dividen Perusahaan Syariah Yang Terdaftar Di Bursa Efek Indonesia. Economac, Volume 12, Nomor 1, April 2012, hlm $9-14$.

Mulyawan, Setia. 2015. Manajemen Keuangan. Bandung: Pustaka Setia.

Musthafa. 2017. Manajemen Keuangan. Yogyakarta: Penerbit ANDI.

Sinaga, Poltak. 2014.Manajemen Keuangan : Teori dan Aplikasi. Medan: CV Mitra.

Sudana, I. Made. 2015. Manajemen Keuangan Perusahaan. Jakarta: Erlangga 